\title{
Study on the Development of the Criminal Procedure Law in the New Media
}

\author{
Xingcun Liao \\ Jiangsu Police Institute, Nanjing Jiangsu, 210034, China
}

Key words: The new media era, The criminal procedure law, Social value ,Trend.

\begin{abstract}
Based on gradually mature legal system in our country, in the process of the establishment of Law research project, it is appropriated to control the positive integration of Internet knowledge and related content in combination with the actual requirements, so as to ensure the application of Internet technology for realizing the information and convenient of the the criminal procedure law and constructing the completed criminal procedural law system with the times feature. taking the background of the development of the criminal procedure law in the new media into account, this paper centrally analyzing the actual social value and discussing the optimization path and the future development trend, so as to provide valuable references for relevant researchers.
\end{abstract}

\section{Introduction}

The new media era has promoted the development of different industries. For the study of criminal procedure law, there are important practical values to construct the architecture of dynamic management and development model with more significance and value of research. Therefore, the relevant departments should pay high attention to it and make a in-depth research on the future development trend and optimization measures, as a result of which, it will give full play to the actual social utility

\section{The Background of Development of The Criminal Procedure Law in the New Media}

The coming of the era opened the new door of new media interactive media. By means of newspapers and magazines and other paper products, the traditional media can transfer and communicate information with corresponding single information transmission medium and the service mode. China's new media era gradually formed with the development of science and technology, realizing the data transmission and information exchange with digital technology and network information technology and achieving remote information connection with mobile technology services, as well as establishing convenient mobile terminal the Internet, wireless networks and other communication channels which can realize the remote interaction of information, so as to truly realize the new service model in the actual management structure. The era of new media, achieving the international exchange, not only broke the traditional exchange mechanism and interaction mode, but also occupied a very important operation significance in the social development system, as a result of which, the change also has an impact on the legal system. For litigant participant in Criminal Procedure Law, it should protect the innocent from criminal prosecution in the process of disclosure, confirm or the punishment of crime. Combined with the new media mechanism, would form a new development path and operation trend, as well as a important path of law system and international standards, which is even an inevitable trend of development of the times. 


\section{The social value the development of the criminal procedure law in the new media}

\section{Gradually improvement of the system of criminal procedure law in the new media}

In recent years, the new media era in China is showing a rapid development trend with changes in the adaptation of social politics and economy, introducing different social models and new social resources. On the basis of perfecting water system, this is why the criminal procedure law influenced by different social new trends should further adapt the social dynamic changes to conform to the trend of the times. In the process of the project transformation, family, as the representative of social organizations and digital media, plays a very important role, which also provides a solid impetus to the socialization of criminal procedure law. It is hoped to know how to effectively change the traditional model and change the old system of criminal procedure law. Combined with actual demand, the relevant departments should construct a more systematic operation system and management requirements and actively implement the corresponding control measures, so as to have a positive impact on the pattern of the old criminal procedure. Relevant departments construct a operation with democracy and nomocracy, which also laid a solid foundation for the upgrading and optimization of the entire criminal litigation research. That is to say, faced with the background of new media era, the development of criminal procedure in China has not only achieved an effective project transformation, but also paid more attention to the participation of social groups, as a result of which, it has upgraded the operational dimension of the litigation management model from the reality.

\section{The gradually improved research achievements of the criminal procedure law in new media era}

In the new media age, in addition to changes of the corresponding operating mechanism, the exchange of information is also more convenient and orderly in various fields. Using different communication channels for information and data exchange, the relevant department constructs an effective digital information network, which provides the impetus for the relevant project upgrades. It is the convenience and sharing of platform communication in the internet that ensure the diversity of the research model and the research mechanism, and optimize the research on the theory of criminal procedure law in China in combination with sharing system. Taking the viewing angle into account, it is found that the content and structure of the traditional criminal procedure is relatively simple. With the help of new media networking, it is appropriate to improve legal awareness and related concepts, and ensure the depth of information flow, so as to make a more fitting in corresponding decision and management items, which is more convincing with comprehensive and diversification. In addition, due to the help of new media model and relevant information mechanism, it can establish a project emphasized on the human rights protection and judicial fairness in the process of theoretical research of Criminal Procedure Law. According to the relevant results and information dimension, it can also construct an effective information controlling hierarchy, which can change the traditional pattern of single punishment crime. That is to say, the integration of new media era and law project strengthen the management and law enforcement concept of people-oriented, deeply realize the optimization of criminal procedure law and fundamentally improve the integrity of the whole legal system, as a result which, it achieve legal operational target of substantive justice and procedural justice. Based on the practice of theoretical innovation, it is hoped to conform to the trend of the times and the national mainstream, and establish a new media management model with Chinese characteristics. While enriching the theory of criminal procedure law, it can realize the comprehensive reform and renewal of the criminal procedure law, which has a particularly important significance for the transmission of legal consciousness and the promotion of China's international status

\section{The gradually improved means of the criminal procedure law in new media era}

Based on the cognition of traditional criminal procedure, in the process of construction and operation of the actual management mechanism, the inference method and analysis are the development 
systems in the important mode of the criminal procedure law. The former is the possible development trend of the case and the latter is an analysis of the existing evidence. Corresponding management model still has some deficiencies between the data support and the social theory management, which needs further excavation [2] .This, is why new media development model would absorb the traditional means of criminal procedure to enhance the overall management effect and operational dimension. With the rapid development of network technology in the new media era,it is high time to realize the communicating convenience and fluency to make a direct interaction and information dissemination. the upgrading of the overall operation and maintenance system and management model can effectively improve the overall control effect of the actual value and ensure that the corresponding information can be more effective treatment and comprehensive maintenance, so as to ensure that the criminal procedure law of our country has realized the systematic escalation and innovation in the research mechanism. Collecting and integrating the information and data on the mobile terminal, with internet communication platform, would conduct information research focused on criminal procedure legislation in the society by means of questionnaire, so as to further broaden the way for citizens to participate in the criminal procedure law of our country, which is an important measure in the social development model. In addition, combined the criminal litigation model with internet system, would fundamentally improve the effectiveness of the overall operation and help to stimulate social vitality and maintain social stability.

\section{The gradually improved research of criminal procedure law in the new media era}

The cognition of the criminal procedure law still stays in the traditional structure, without tight relationship between the related projects and social development trends. There are still many deficiencies in China's criminal procedure law. For instant, the high attention on the criminal litigation management mechanism lead to the severe recurrent in the research mechanism and research process, as a result of which, the relevant information can not be effectively processed and integrated. In addition, there are some serious problems in Interdisciplinary opinion model and the absence of management dimension. In the traditional criminal procedure law system, there is comparatively little knowledge about the criminal procedure law in foreign countries, which leads to the lack of the corresponding exchange system and the operation management. With the development of new media era, it also changes in the relevant information management mechanism and operational dimension. Relying on the digital information era is an practical and effective solutions to ensure the operational dimension and management requirements of the related project more practicable. In the new media era, the Internet has been highly valued by various industries with the efficient office skills, not only to improve office efficiency, but also to bring the latest news and data of the international advanced criminal procedure law, which is an effective learning path to fundamentally improve the ability of data processing mechanism and optimize, as well as to promote the structure optimization of the single subject and interdisciplinary. the Internet and new media interactive platform are used to achieve the timely sharing of the international and domestic hot spot and focal point [3].In the process of high efficiency of internet, it is more appropriate to construct a positive and complete collision model, which makes the structure of the whole system of criminal procedure law more clear in our country and achieve a breakthrough of the relevant information dimension. Motivated by new ideas and new ideas, the operational dimension establish operation system to meet the development needs and upgrade the social value of criminal procedure, which have a serious influence on Legislation research system around the world.

\section{Optimization path and development trend of the development of criminal procedural law in the new media era}

\section{The establishment of efficient litigation system in the new media era}

Based on the changes of the overall management model and control requirements in the new media era, it is appropriated to fit the actual operation and maintenance system combined with the network 
information platform construction to ensure the development and effect of social security fundamentally. It is found that it can ensure the compactness between the Information exchange project and Control requirements, further enhance the effectiveness of media and maintain the Structure and model of the social development with the new media. Only by ensuring the fairness and efficiency of criminal procedure, can we maintain its authority and comprehensiveness to ensure the effectiveness of the value dimension and the management mechanism. In addition, for the research of criminal procedure law, only to achieve fairness and justice, it can truly play the value and significance of constructing a harmonious society.

\section{The improvement of the attention of criminal procedure law in the new media era}

For network operation characteristics of the new media era, the network information can achieve efficient transmission and facilitation sharing, which lead to more cognition on the project of criminal procedural law and gradually improve the corresponding attention. It is the inevitable trend of our times, as well as the basic composition of the developing concept of criminal procedural law, meeting the rapid development of China's economy and the establish demand of the law society. In daily life, people make a discuss and pay more attention to the relationship between the theory and practice of criminal procedure law in China. Meanwhile, establishing own view on the existing problems in consideration of program information and practice cases and expressing your own suggestions on the online and offline platforms, would ensure to form a development model where anyone knows and comply with the national law. In addition, in combination with the help of related platform structure, it can improve the government credibility and play an important positive role in maintaining the fairness and impartiality, as well as a product of the times to deter criminals.

\section{The construction of interactive communication platform in New Media Era}

Similar with enhancing the attention, the relevant departments should build a more complete network platform with the real needs of the region, which can ensure the freedom of opinion and expression in the new media era, not only to improve the comprehensive level for criminal law enforcement and legislation, but also to handle deeply and explore comprehensively the fairness of the related project management combined with the mass participation dimension. Upholding the working attitude of leniency, collecting and collating the reasonable statements and suggestions, would ensure that the project of the criminal procedure law can achieve sustainable development. Therefore, it is extremely significant to deal with the discordant voices, fundamentally eliminate malicious incitement information and avoid the public uneasy voice, so as to maintain its integrity and fairness in the new media era.

\section{Realization theory and Practice Fusion of the new media era}

Any theory that want to obtain rapid development should effectively combine with practice to ensure the system upgrade between the corresponding management dimension and control model and improve the China socialism development power further, so as to ensure that the relevant concept of the criminal procedure law can be matured enough. Based on the guidance of theoretical model, would ensure the optimal application value by making the diversified analysis and centralized control in according with the actual situation. Based on the management dimension of theory and practice, it can realize the scientific integration goals and ensure that theoretical research can really develop its practical value and implementation meaning.

\section{Conclusion}

To summaries, faced with the background of new media, there is an optimization in the research field and the effect on the criminal procedure law, which is characterized by the convenient in the relevant information structure and theoretical model, so as to conform to the trend of times and meet the relevant requirements of international interaction system. Maintaining the research value of the law of socialist Chinese characteristics and combining the international development trend, would ensure 
human rights respected and lay a solid foundation for the further construction of the harmonious social atmosphere.

\section{Acknowledgement}

Funded projects of Jiangsu Police Institute（2016SJYSY09）.

\section{References}

[1] Weng Jianyu. Empirical Analysis of the Relationship Between Public Opinion and Criminal Justice under the New Media Environment---- a Case Study of Sexual Abuse of Young Girls, Zhejiang University, 2016.

[2] Jin Feng Qian. Rethinking of the Whole Process of Recording under the New Situation -Inspired by the New Legislation and Judicial Interpretation, Youth Science (teacher's Edition), 2013,34 (04): 67-69.

[3] Zhang Wenjun, Wang Daodong. Discussion on the Influence and Countermeasures of the Implementation of the New Criminal Procedure Evidence System to the Investigation and Evidence Collection, Journal of Hunan Police Academy, 2014,26 (06): 24-30.

[4] Li Lingyun. Discussion on the Application of Electronic Evidence--from the Perspective of the Application of Procuratorial Organs in Criminal Proceedings, Shandong University, 2013.

[5] Shu Caizhong. Thoughts on how to Develop the Self Investigation Work of Procuratorate under the New Criminal Procedure Law, legal system and society, 2013,15 (28): 77-78. 